\title{
Importance Understanding Rights and Obligations Citizens in Election Head of Medan City District 2020
}

\author{
Faiz Albar Nasution ${ }^{1 *}$, Muhammad Husni Thamrin ${ }^{2}$, Muhammad Arifin Nasution ${ }^{2}$, Fernanda \\ Putra Adela ${ }^{1}$, Saipul Bahri ${ }^{1}$ \\ ${ }^{1}$ Program Studi Ilmu Politik, Fakultas Ilmu Sosial dan Ilmu Politik, Universitas Sumatera \\ Utara \\ ${ }^{2}$ Program Studi Ilmu Administrasi Publik, Fakultas Ilmu Sosial dan Ilmu Politik, Universitas \\ Sumatera Utara \\ *Email: faiznasution92@gmail.com
}

\begin{abstract}
Participation of citizens in using voting rights as a key element to success of Election. However, voter participation in Medan regional elections since reforms until now, tends experience a low participation rate. Thus, political socialization education is important, in order to maintain quantity and quality in the 2020 Medan City Head Election. The objectives of this activity include: First, disseminating information about the stages, schedule and objectives of the election. Second, increase citizens' knowledge and awareness of rights and obligations in elections. Third, increase voter participation in elections. Method of socialization through lectures and discussions from speakers to activity participants by applying strict health protocols.. The results of socialization activities show the enthusiastic attitude of the Community of the Sovereign People's Movement of North Sumatra in participating in this activity. Socialization participants argue that this activity can increase their knowledge of the rights and obligations of citizens ahead of the Election. Evidently, socialization participants are committed to participate in inviting the people of Medan to participate and follow the entire process of the simultaneous election stage 2020.
\end{abstract}

Keyword: Rights, Obligations, Election Regional Heads

\begin{abstract}
Abstrak
Partisipasi warga dalam menggunakan hak pilih menjadi elemen utama terhadap keberhasilan pemilihan. Akan tetapi, partisipasi pemilih di Pemilihan Kepala Daerah Kota Medan sejak reformasi hingga saat ini,cenderung mengalami tingkat partisipasi yang rendah. Dengan demikian, pendidikan dan sosialisasi politik penting dilakukan, guna menjaga kuantitas dan kualitas di Pemilihan Kepala Daerah Kota Medan tahun 2020. Tujuan dari kegiatan ini antara lain: Pertama, menyebarluaskan informasi mengenai tahapan, jadwal dan tujuan pemilihan. Kedua, meningkatkan pengetahuan dan kesadaran warga tentang hak dan kewajiban dalam pemilihan. Ketiga, meningkatkan partisipasi pemilih dalam pemilihan. Metode sosialisasi melalui ceramah dan diskusi dari narasumber terhadap peserta kegiatan dengan menerapkan protokol kesehatan secara ketat. Hasil kegiatan sosialisasi menunjukkan adanya sikap antusias dari komunitas Gerakan Rakyat Berdaulat Sumatera Utara dalam mengikuti kegiatan ini. Peserta sosialisasi berpendapat bahwa kegiatan ini dapat meningkatkan pengetahuan mereka tentang hak dan kewajiban warga menjelang Pemilihan. Terbukti, peserta sosialisasi berkomitmen untuk ikut serta mengajak warga Kota Medan dalam berpartisipasi dan mengikuti seluruh proses tahapan Pilkada serentak 2020.
\end{abstract}

Kata Kunci: Hak, Kewajiban, Pemilihan Kepala Daerah

\section{PENDAhULUAN}

Partisipasi warga dalam menggunakan hak pilih menjadi elemen utama terhadap keberhasilan pemilihan (Nasution, 2019). Terlebih lagi, Undang - Undang Nomor 10 Tahun 2016 
mengamanatkan warga untuk berpartisipasi dalam menentukan kebijakan di daerah. Dengan demikian, Pilkada serentak tahun 2020 di tengah pandemi, warga Kota Medan akan memilih Walikota dan Wakil Walikota Medan. Akan tetapi partisipasi warga Kota Medan pada Pemilihan Walikota Medan tidak pernah menyentuh angka 60\% (Thamrin, 2020). Terbukti, Pemilihan Walikota Medan tahun 2005 partisipasi mencapai 54,70\%, Pemilihan Walikota Medan tahun 2010 partisipasi sebesar 36,28\% dan Pemilihan Walikota Medan tahun 2015 partisipasi hanya 25,38\% (Kpu Kota Medan, 2019).

Perilaku tidak memilih di Pemilihan Walikota Medan mengindikasikan bahwa warga Kota Medan tidak memiliki kesadaran politik dalam memilih (Nasution, 2020). Maka dari itu, meningkatkan kesadaran politik warga penting untuk dilakukan (Harahap, 2019). Menyitir Ramlan Surbakti membuktikan bahwa warga yang memiliki kesadaran politik yang tinggi, partisipasi politik cenderung aktif. Sebaliknya, kesadaran politik warga rendah, partisipasi politik cenderung pasif atau apatis. Kendati demikian, kesadaran politik berupa kesadaran hak dan kewajiban sebagai warga negara untuk ikut serta dalam setiap kegiatan Pemilu (Surbakti, 2010).

Sejalan dengan penelitian terdahulu, Sri Juniarti membuktikan peningkatan partisipasi warga dipengaruhi pendidikan politik dan sosialisasi politik pada Pemilihan (Hasibuan, 2018). Sebaliknya, rendahnya partispasi warga dalam menggunakan hak pilih disebabkan kegiatan sosialisasi dan pendidikan politik yang terbatas (Siringoringo, 2016). Lebih lanjut, studi Filla \& Johnson menegaskan bahwa informasi tentang tahapan Pemilihan akan mempengaruhi jumlah pemilih di daerah (Filla \& Johnson, 2010). Sehingga, memberikan sosialisasi tentang pentingnya memahami hak dan kewajiban warga di Pilkada Kota Medan penitng untuk dilakukan. Kegiatan tersebut, guna meningkatkan kuantitas dan kualitas demokrasi di Pilkada Kota Medan tahun 2020.

\section{METODE PELAKSANAAN}

Kegiatan ini dilakukan pada 07 Oktober 2020, bertempat di Yayasan Pendidikan Bina Taruna Jaya, Kecamatan Medan Marelan, Kota Medan. Adapun peserta kegiatan adalah Komunitas Gerakan Rakyat Berdaulat Sumatera Utara. Lebih lanjut, tujuan kegiatan antara lain: Pertama, menyebarluaskan informasi mengenai tahapan, jadwal dan tujuan pemilihan. Kedua, meningkatkan pengetahuan dan kesadaran warga tentang hak dan kewajiban dalam pemilihan. Ketiga, meningkatkan partisipasi pemilih dalam pemilihan.

Adapun metode kegiatan sosialisasi dilakukan dengan cermah dan diskusi, antara lain:

1. Metode ceramah dilakukan guna meningkatkan kesadaran warga tentang hak dan kewajiban dalam pemilihan.

2. Metode diskusi diterapkan agar peserta kegiatan dapat memahami materi yang telah disampaikan dan proses tanya jawab terhadap narasumber akan memperluas pemahaman peserta.

\section{HASIL DAN PEMBAHASAN}

Secara umum hasil kegiatan sosialisasi menghadirkan para pemilih komunitas Gerakan Rakyat Berdaulat Sumatera Utara di Kota Medan. Kegiatan tersebut, telah diikuti 30 orang peserta, terdiri dari BPH (Badan Pengurus Harian) dan anggota komunitas Gerakan Rakyat Berdaulat Sumatera Utara yang berdomisili di Kecamatan Medan Marelan. Kegiatan tersebut, menunjukkan peserta sangat antusias mengikuti sosialisasi ini. Sebelum rangkaian acara, para peserta dan tamu undangan melakukan registrasi dengan menerapkan protokol kesehatan secara ketat. Prosedur ini dilakukan agar para peserta dan tamu undangan dapat terjaga kesehatannya dan terbebas dari ancaman virus Covid-19.

Narasumber kegiatan Sosialisasi ini adalah Edy Suhartono selaku Komisioner KPU Kota Medan dan Hatta Ridho sebagai Akademisi FISIP Universitas Sumatera Utara. Terlebih dahulu, Edi Suhartono mengajak peserta untuk mencocokan data pemilih peserta melalui website lindungihakpilihmu.kpu.go.id. Kegiatan ini bertujuan agar seluruh peserta kegiatan terdaftar sebagai 
pemilih dan melaporkan kepada KPU apabila belum dilakukan pencocokan dan penelitian (coklit) secara faktual. Lebih lanjut, narasumber menjelaskan asas - asas pemilihan, pentingnya memahami proses dan tahapan pilkada, serta mematuhi protokol kesehatan. Penjelasan materi telah disampaikan selama 30 menit dan 20 menit untuk melakukan sesi Tanya jawab.
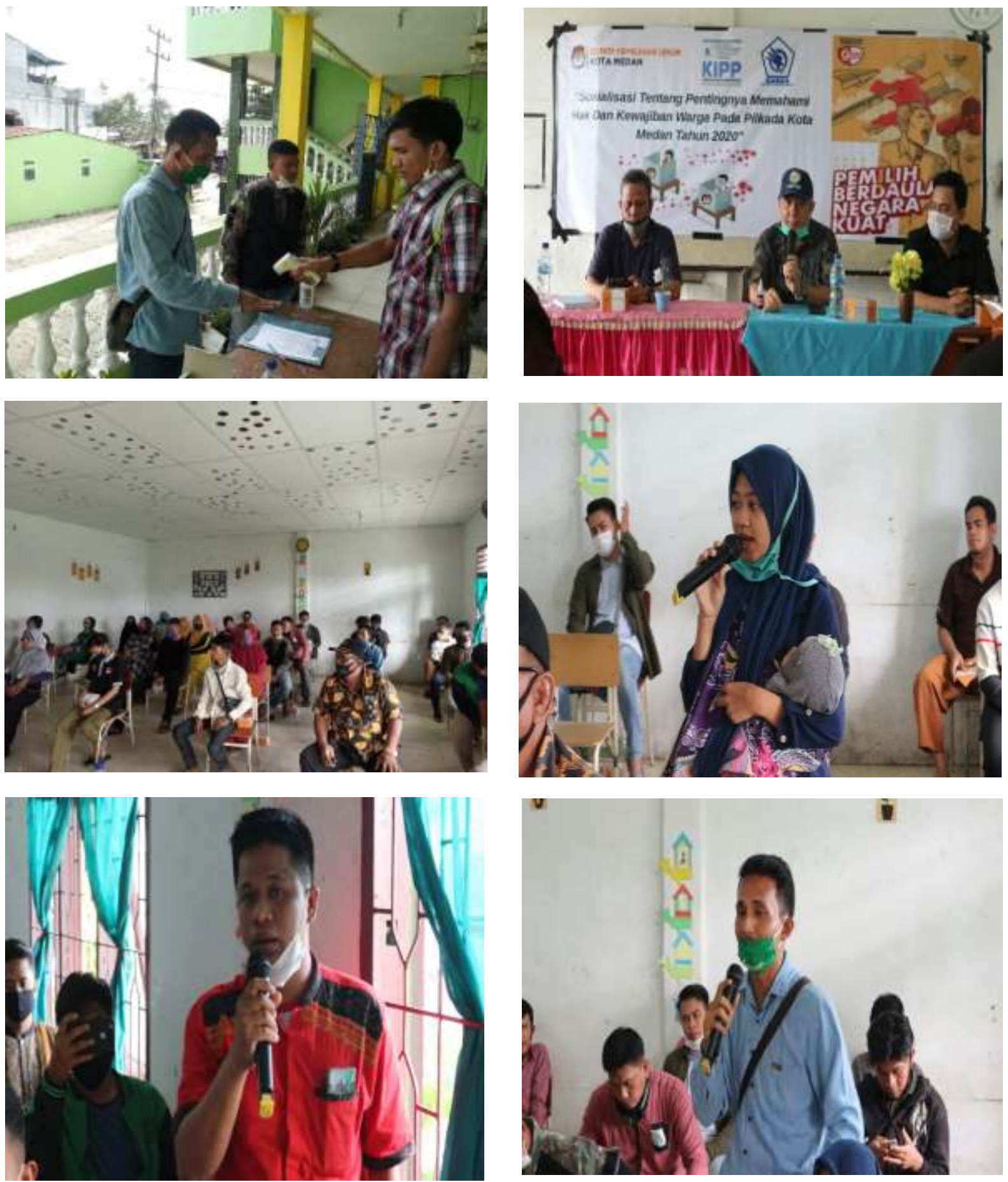

Gambar 3.1 Kegiatan Sosialisasi Tentang Pentingnya Memahami Hak Dan Kewajiban Warga Pada Pemilihan Kepala Daerah Kota Medan tahun 2020

Penyampaian materi yang telah selesai, maka dilanjutkan dengan sesi diskusi/tanya jawab. Adapun beberapa pertanyaan dari peserta antara lain; Pertama, mengapa politik uang masih terjadi. 
Kedua, mengapa Kepala Daerah yang dihasilkan dari Pilkada selalu terjerat korupsi. Ketiga, jaminan seperti apa yang bisa diberikaan terhadap kesehatan warga pada Pilkada di tengah pandemi. Keempat, bagaimana cara meningkatkan partisipasi pemilih.

Secara umum kegiatan ini mampu meningkatkan kesadaran peserta. Sebab peserta kegiatan dalam memberi pertanyaan dipengaruhi atas kepedulian terhadap buruknya kinerja Kepala Daerah sebelumnya. Peserta kegiatan sangat mengharapkan Pilkada Kota Medan 2020 melahirkan pemimpin yang visioner dan inovatif. Sehingga masalah publik di Kota Medan seperti sampah, banjir, jalan rusak dan korupsi dapat diperbaiki (Ratna, 2018; CNN Indonesia, 2019; Tigor, 2019; Yoseph, 2019).

Hatta Ridho sebagai Narasumber kedua menyampaikan materi dalam kurun waktu 30 menit. Materi yang disampaikan narasumber tentang masalah pembangunan Kota Medan, pentingnya menggunakan hak pilih bagi warga Kota Medan, berpartisipasi dalam merumuskan dan mengontrol kebijakan terhadap Kepala Daerah terpilih. Materi tersebut meliputi: Pertama, hak pilih adalah hak istimewa setiap warga negara. Kedua, memilih untuk perubahan menjadi Kota yang lebih maju. Ketiga, memilih agar lahir Kepala Daerah yang berkualitas dan mengontrol anggaran agar tidak siasia.

Setelah penyampaian materi, narasumber dan peserta kegiatan melakukan interaksi tanya jawab. Beberapa pertanyaan yang telah disampaikam antara lain: Pertama, apa saja yang mempengaruhi fasilitas publik di Kota Medan buruk. Kedua, bagaimana rekrutmen politik yang dilakukan partai politik dalam mencalonkan Kepala Daerah. Ketiga, mengapa warga Kota Medan harus memilih yang pada akhirnya akan menciptakan pemimpin yang buruk. Keempat, bagaimana cara ikut serta memberi masukan dan mengontrol kebijakan terhadap pemerintah Kota Medan.

Beberapa Pertanyaan yang telah disampaikan peserta kegiatan berhubungan dengan pertanyaan sebelumnya. Kondisi tersebut, cukup menggambarkan warga Kota Medan memahami masalah - masalah di Kota Medan (Cahyono, 2019). lebih lanjut, warga Kota Medan sangat berharap untuk diyakinkan agar ikut serta dalam Pemilihan (Adela, 2017). Dengan demikian, dibutuhkan inovasi lainnya terhadap KPU Kota Medan untuk melakukan sosialisasi politik, pendidikan politik, kampanye dan debat calon (Nazlia, 2019). Sehingga Pilkada di tengah pandemi masyarakat teredukasi dan cerdas dalam mengambil peran di seluruh tahapan proses Pilkada.

Sosialisasi terhadap pemilih komunitas Gerakan Rakyat Berdaulat Sumatera Utara mampu meningkatkan kesadaran politik akan pentingnya memahami hak dan kewajiban warga pada Pemilihan. Selain itu, memberikan hak suara menjadi bagian penting untuk mendapatkan pemimpin yang baik di Kota Medan. Para peserta semulanya kurang yakin dan kurang berani untuk ikut terlibat memberikan hak suaranya di TPS. Akan tetapi, intensitas sosialisasi yang dilakukan dapat mempengaruhi mereka, agar yakin dan berani untuk datang ke TPS. Sebab, narasumber dari KPU Kota Medan dan Akademisi FISIP USU telah meyakinkan dan memastikan kepada peserta bahwa dalam proses penyelenggaraan pemilihan di TPS akan mematuhi protokol kesehatan secara ketat. Dengan adanya proses sosialisasi ini, tim pelaksana kegiatan berhasil membuat para peserta terstimulus untuk terlibat langsung dalam memberikan hak suara di TPS nantinya.

\section{KESIMPULAN}

Hasil kegiatan sosialisasi menunjukkan adanya sikap antusias dari komunitas Gerakan Rakyat Berdaulat Sumatera Utara dalam mengikuti kegiatan ini. Selain itu, peserta sosialisasi berpendapat bahwa kegiatan ini dapat meningkatkan pengetahuan mereka tentang hak dan kewajiban warga menjelang Pemilihan. Terbukti, peserta sosialisasi berkomitmen untuk ikut serta mengajak warga Kota Medan dalam berpartisipasi dan mengikuti seluruh proses tahapan Pilkada serentak 2020. Harapannya, pendidikan dan sosialisasi politik harus gencar dilakukan KPU Kota Medan, guna memastikan warga ikut serta memilih pada Pilkada di tengah pandemi. Dengan demikian, masyarakat tidak lagi cemas untuk datang ke TPS dan tingkat partisipasi akan meningkat di Pilkada Kota Medan 2020. 


\section{UCAPAN TERIMAKASIH}

Ucapan terima kasih terutama ditujukan kepada Komisi Pemilihan Umum Kota Medan yang telah mendanai kegiatan sosialisasi ini. Selain itu, terima kasih atas dukungan Pengurus Komite Independen Pemantau Pemilu Wilayah Sumatera Utara dalam mensukseskan kegiatan ini. Terlebih lagi, terima kasih kepada para pihak - pihak yang telah memberikan sumbangsihnya terhadap kegiatan sosialisasi ini.

\section{DAFTAR PUSTAKA}

Adela, F. P., \& Truna, D.S. (2017). Partisipasi Rakyat Dalam Pengawasan Pilkada, Antisipasi Tingginya Angka Golput Di Pilkada Sumut 2018. Jurnal Bawaslu, 3(1), 107-118. Retrieved from http://jurnal.bawaslu.go.id/Edisi-I.pdf\#page=112

Cahyono, S. (2019). Wali Kota Medan Dapat Ucapan Selamat atas Predikat Kota Terjorok. Jawapos.Com, p. 1. Retrieved from https://www.jawapos.com/jpg-today/23/01/2019/walikota-medan-dapat-ucapan-selamat-atas-predikat-kota-terjorok/

CNN Indonesia. (2019). Tiga Wali Kota Medan Berturut-turut Terjerat Korupsi. Cnn Indonesia.Com, p.1.Retrieved from https://www.cnnindonesia.com/nasional/20191016165658-12-440068/tiga-wali-kotamedan-berturut-turut-terjerat-korupsi

Filla., \& Johnson. (2010). Local News Outlets and Political Participation. Journals.Sagepub.Com, 45(5), 679-692. https://doi.org/10.1177/1078087409351947

Harahap, H. I. (2019, July). Hate Speech in Election: Increasing Trends and Concerns. In 1st International Conference on Life, Innovation, Change and Knowledge (ICLICK 2018) (pp. 44-46). Atlantis Press. https://doi.org/10.2991/iclick-18.2019.10

Hasibuan, S. J., Kadir, A., \& Nasution, M.H.T. (2018). Strategi Komisi Pemilihan Umum Provinsi Sumatera Utara Dalam Meningkatkan Partisipasi Masyarakat Pada Pemilihan Gubernur $\begin{array}{lllll}\text { Sumatera } & \text { Utara } & 2018 . & \text { PERSPEKTIF, }\end{array}$ https://doi.org/10.31289/perspektif.v7i1.2519

Kpu Kota Medan. (2019). Trend Kehadiran Pada Pemilihan Umum dan Pilkada Kota Meda Sejak Tahun 2004 S/D 2019. Retrieved from https://kpud-medankota.go.id/

Nasution, F. A., \& Kushandajani, K. (2019). Partisipasi Politik Masyarakat Kecamatan Medan Maimun Pada Pemilihan Gubernur Sumatera Utara Tahun 2018. JPPUMA Jurnal Ilmu Pemerintahan dan Sosial Politik Universitas Medan Area, 7(2), 227-235. https://doi.org/10.31289/jppuma.v7i2.3015

Nasution, F. A. (2020). Menakar Partisipasi Politik Masyarakat Kota Medan Terhadap Pemilihan Walikota Medan Tahun 2020: Indonesia. Politeia: Jurnal Ilmu Politik, 12(2), 97-113. Retrieved from https://talenta.usu.ac.id/politeia/article/view/3955

Nazlia, N. (2019). Peranan Komisi Pemilihan Umum Kota Medan Dalam Memberikan Pendidikan Politik Bagi Penyandang Disabilitas. Jurnal Ilmu Pemerintahan, Administrasi Publik, Ilmu Komunikasi 
https://doi.org/http://jurnalmahasiswa.uma.ac.id/index.php/jipikom/article/view/139

Ratna, P. (2018). ICW : Medan Kota paling rawan korupsi. Republika.Co.Id. Retrieved from https://www.republika.co.id/berita/nasional/hukum/18/06/04/p9rd7v428-icw-medan-kotapaling-rawan-korupsi

Siringoringo, F. P. (2016). Lemahnya Upaya KPU Kota Medan Dalam Meminimalisir Rendahnya Partisipasi Politik Pada Pemilihan Walikota Medan Tahun 2015. Universitas Negeri Medan.

Surbakti, R. (2010). Memahami Ilmu Politik. (F. A. Herfan Djoni, Ed.) (VII). Jakarta: PT Grasindo.

Thamrin, M. H., Nasution, M.A., \& Nasution, F.A. (2020). Problematik Data Pemilih pada Pemilihan Kepala Daerah Tahun 2018 Di Kota Medan. JURNAL SOSIAL POLITIK, 6(2), 157-167. https://doi.org/10.22219/sospol.v6i2.11367

Tigor, M. (2019). Hujan Sebentar Kota Medan Banjir, Drainase Buruk. Tagar.Id. Retrieved from https://www.tagar.id/hujan-sebentar-kota-medan-banjir-drainase-buruk

Yoseph, P. (2019). Sandang Predikat Kota Terjorok, Pemkot Medan Berkelit. Media Indonesia. Retrieved from https://mediaindonesia.com/read/detail/210731-sandang-predikat-kotaterjorok-pemkot-medan-berkelit 